\title{
Brief summary of the Hungarian test method (MSZ 14800-6:2009) of fire propagation on building façades
}

\author{
István Móder, Ádám Varga, Péter Geier, Bálint Vágó and Edit Rajna \\ Non-Profit Limited Liability Company for Quality Control and Innovation in Building, \\ Szentendre, Hungary
}

\begin{abstract}
When a fully developed fire from one compartment of a building spreads from a window to a façade, it is considered to be one of the most dangerous causes of fire propagation on façades. The Hungarian test method described in standard MSZ 14800-6:2009 focuses on determining the effect and risk evaluation of combustible façade materials by modelling a heat release of a compartment/office fire scenario in a model building with realistic construction and detail types. The method provides actual fire spread limit $\left(T_{\mathrm{h}}\right)$ in minutes and an evaluation method as well.
\end{abstract}

\section{INTRODUCTION}

The main causes of fire spread on façade can be led back to one of the following three main reasons. A fully developed fire from at least one compartment of a building spreads from a window to a façade. Materials and goods placed in front of a façade get on fire causing fire propagation on the façade. Fire spreads from one building to another one. The first one is considered to be the most dangerous and common one. The Hungarian test method focuses on determining the effect and risk evaluation of combustible façade materials in case of fire.

Origin of the current test method dates back to 1974. During the last four decades the test standard got improved on modelling actual room/office fire. The test method described in standard MSZ 148006:2009 [1] models the heat release of a compartment/office fire scenario in a model building with realistic construction types and detail solutions. The method provides actual fire spread limit $\left(T_{\mathrm{h}}\right)$ in minutes and an evaluation method as well.

So far only one laboratory (Non-Profit Limited Liability Company for Quality Control and Innovation in Building) has got accredited for this test standard since 2009, up to this date over one hundred tests were carried out forming a solid experience and knowledge about the standard within the Laboratory.

During the current standardization work in Europe the outcome of work and effort which were put into developing this standard needs to be shared.

This is an Open Access article distributed under the terms of the Creative Commons Attribution License 2.0, which permits unrestricted use, distribution, and reproduction in any medium, provided the original work is properly cited. 


\section{TEST METHOD}

The scope of this test method is determining the vertical and horizontal fire propagation on building façades which contain openings (window, French balcony etc.) where the wall is finished with combustible materials (such as ETICS), or ventilated or not ventilated cladding systems. Other aim is to determine the effect of façade design solutions that do not satisfy the fire barrier criteria of $1.30(\mathrm{~m})$ stated in the Hungarian Fire Code [2].

The outdoor test rig is a 3-storey high building, the ground floor is the fire chamber, the second and third floors are the observing levels. The façade is made according to the end use application of the product to be tested; ETICS are usually tested on aerated concrete walls. The façade has standardized window openings with dimensions of $1.20(\mathrm{~m}) \times 1.20(\mathrm{~m})$. On the level of fire chamber an openable timber frame window is installed before every test.

One of the main concepts of this test method is to model a fully developed fire in one compartment of a building and control the fire propagation on the façade to one level above. Several heating curves are used in fire testing. Using standardized internal exposure for modelling one compartment fire is an unquestionable fact. This is the reason why a standard heating curve is used in this test standard for testing fire propagation on façades.

The fire chamber has a volume of $48.76\left(\mathrm{~m}^{3}\right)$ in which fire source of a $650(\mathrm{~kg})$ timber crib is placed $0.5(\mathrm{~m})$ away from the test chamber's front wall. Timber cribs shall be made out of first class pinewood roof battens with the dimensions of $25 \times 50 \times 1500-2000(\mathrm{~mm})$ while the moisture content shall be controlled within $12 \pm 2(\%)$. Elements have to be placed one element away from each other during forming the crib in the test chamber. This timber crib provides $\sim 3.25 \mathrm{MW}$ energy during the test which is meant to be modelling a fully furnished room (taking into count the calorific values of several combustible materials). This provides the following heating curve in the test chamber for a maximum test period of $45(\mathrm{~min})$ :

$$
T-T_{0}=345 \times \lg (8 t+1)[\mathrm{K}]
$$

where

$T$ is the average temperature in the test chamber, in $\left[{ }^{\circ} \mathrm{C}\right]$

$T_{0}$ is the initial temperature in the test chamber, in $\left[{ }^{\circ} \mathrm{C}\right]$

$t$ is the time, in minutes.

The standard gives tolerance criteria for the heating curve that the Laboratory shall fulfill. For the first 5 (min) of the test no tolerances are given, while for the test period $5<\mathrm{t} \leq 10(\mathrm{~min}) \pm 15(\%)$ and for the test period $\mathrm{t}>10(\mathrm{~min}) \pm 10(\%)$ deviation from the standard heating curve shall not be exceeded.

To achieve a proper combustion of a timber crib and heating curve the timber window is opened after $300 \pm 10$ (sec) from the start of a test and the air ventilation within the fire chamber is controlled by the Laboratory by several air grills.

Temperature data shall be recorded at the following locations: five places in the test chamber $\left(T_{\mathrm{tt}}\right)$, between the test chamber and the first observation floor $10(\mathrm{~cm})$ and $50(\mathrm{~cm})$ away from the parapet at $9-9$ locations $\left(T_{\mathrm{lz}}\right)$ and in the observation floor $10(\mathrm{~cm})$ away from the window opening at 16 locations $\left(T_{\text {any }}\right)$ by using a measurement panel of $1.20(\mathrm{~m}) \times 1.20(\mathrm{~m})$. Additional thermocouples can be used on locations where higher temperature might be expected. Temperature rise is measured due to failure criteria.

\section{CRITERIA AND EVALUATION METHOD}

The fire spread limit on façade $\left(T_{\mathrm{h}}\right)$ is determined in minutes by reaching at least one of the following criteria. Flame spread reaches the highest horizontal line of the parapet wall. Flame spread reaches 


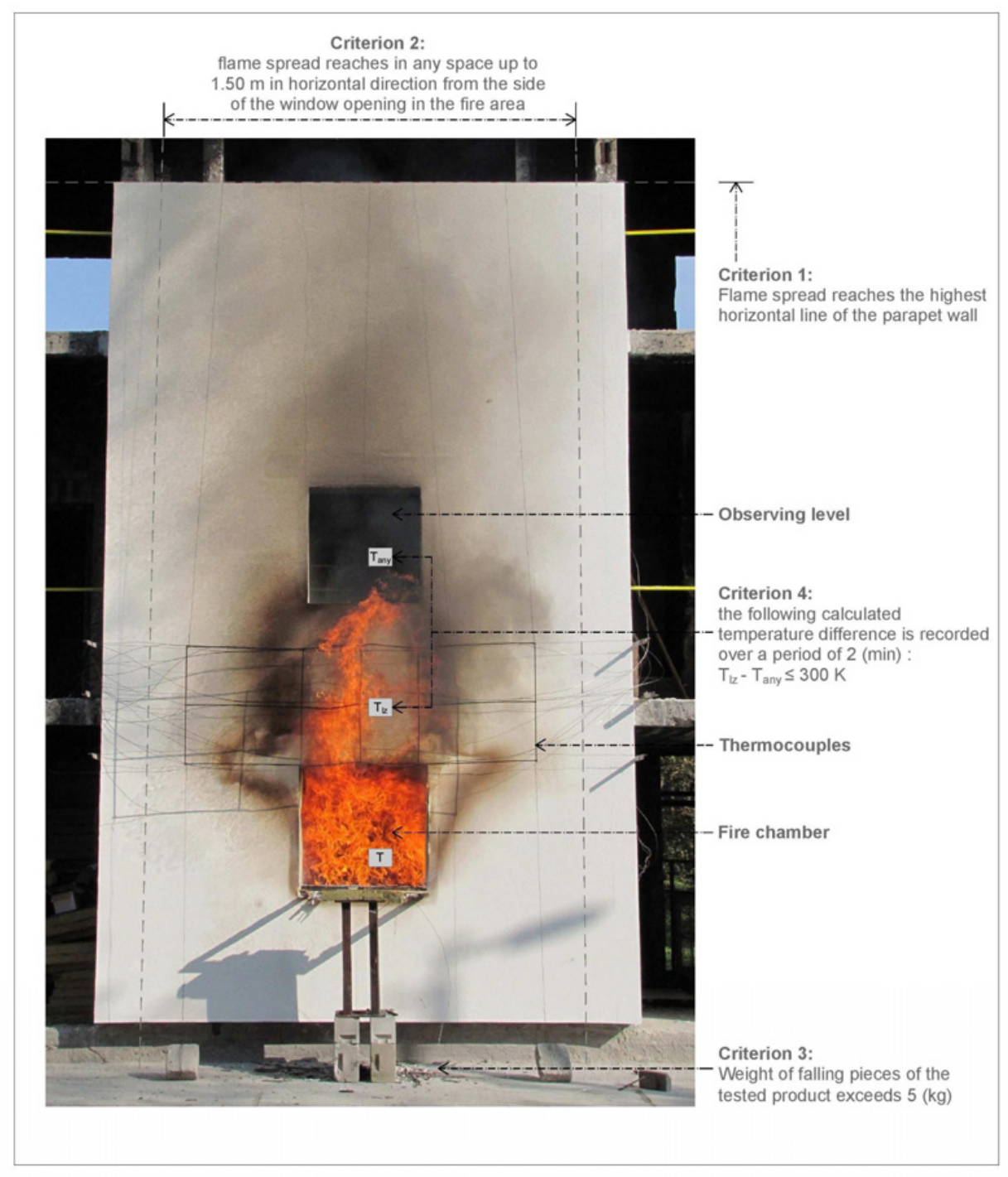

Figure 1. Criteria of MSZ 14800-6:2009.

$1.50(\mathrm{~m})$ width from both sides of the fire chamber's window opening. Weight of falling pieces of the tested product exceeds $5(\mathrm{~kg})$. The following calculated temperature difference is recorded over a period of $2(\min )$ :

$$
T_{l z}-T_{\text {any }} \leq 300[\mathrm{~K}]
$$

The aim of Eq. (2) is to verify that the upstand and downstand (with the kit and cladding system applied on) between the two window opening successfully decreases the effect of flame zone in the observing floor.

The products' fire spread limit on facades can be classified as 15 (min), 30 (min) or 45 (min). According to the current National Fire Code [2], the following minimum requirements are held against fire propagation (reaction to fire requirements are not dealt in this paper). Buildings with ground floor 
and further maximum 2 upper floors $T_{\mathrm{h}} \geq 15(\mathrm{~min})$ requirement shall be met, buildings with ground floor and at least 3 maximum 4 floors $T_{\mathrm{h}} \geq 30(\mathrm{~min})$ while buildings with ground floor and more than 4 floors $T_{\mathrm{h}}=45(\mathrm{~min})$ requirements shall be fulfilled.

Testing and evaluating facades with French balcony without significant fire resistance is out of the scope of this paper. In this case a special hybrid of EN 1634-1 [3] and MSZ 14800-6 shall be used, so far only few tests and evaluations were carried out.

\section{CORRALATION WITH OTHER TEST METHODS}

Currently over 10 national test methods are available in Europe. With each test method numerous amount of tests were carried out therefore a heavy base of experience is gained by each testing laboratory. Each test method has its own concept, ideology and evaluation method behind it, furthermore requirements hold against fire propagation on facades vary from country to country.

Several comparisons of test methods were carried out on very solid - input - aspects [4]. However finding correlation with other test methods' results is almost impossible since the classification - output - is not uniform for all test method. MSZ 14800-6:2009 can only be compared to the "large scale" test methods like Lepir II [5] or SP Fire 105 [6]. Small scale test methods (like the ones described in EOTA draftTR073 [7]) will not be compared to the Hungarian test method in this paper due to significant differences in the aspect of test rig and fire exposure among many.

Considering the inputs of Lepir II have major similarities to the Hungarian test method by applying actual window openings on the ground floor of the test rig and using almost the same amount of fire source (10 (\%) less than at MSZ 14800-6:2009). But the fire exposure time is not the same in the two test methods, and the test rig of Lepir II test method has two window openings on the ground floor, while MSZ 14800-6:2009 has only one. Criteria of SP Fire 105 are almost the same as the ones in the Hungarian test method, such as falling parts and flame spread, however, the Swedish method uses dead windows on the test rig and the fire source is different as well.

ZAG Ljubjana carried out a large scale experiment [8] where the test rig shows big similarities to the Hungarian test rig. The Slovenian test rig consisted of two floors with openable windows installed on each floor. The fire source was higher by 10 (\%) than in MSZ 14800-6:2009 but the test duration was shorter. Both methods applied the standard heating curve (1) during the fire exposure. The temperature measurements were carried out just like in MSZ 14800-6:2009, and even more thermocouples were used and during the experiment, temperature rise were recorded in the insulation material as well.

\section{CONNECTION WITH ACTUAL FIRE CASES}

The aim of all fire testing is to determine products' and kits' response to fire in controlled conditions. Real fire exposures can really vary from the standardized heating curves. During real fires neither fire source, nor combustible material or oxygen amount are controlled - clearly - no measurements are made.

One of the most tragic and widely publicized fire propagation on facades in Hungary was the one in Miskolc at 15 August, 2009. The 10-storey high prefabricated panel building had been rehabilitated in 2007 when external insulation was installed, new insulated windows were installed, and the heating system was modernized as well. The fire broke out in one apartment's kitchen on the $6^{\text {th }}$ floor causing 3 deaths and 12 smoke poisoning. Expert judgements and fire investigations were published on this topic stating that several causes led to the tragedy.

Concerning the ETICS system the following statements were made [9]. The adhesive was not used properly, the leading and overlapping of fiberglass was not adequate, the number of anchors were less than required and the positioning were randomly made, the rendering thickness was half size of 


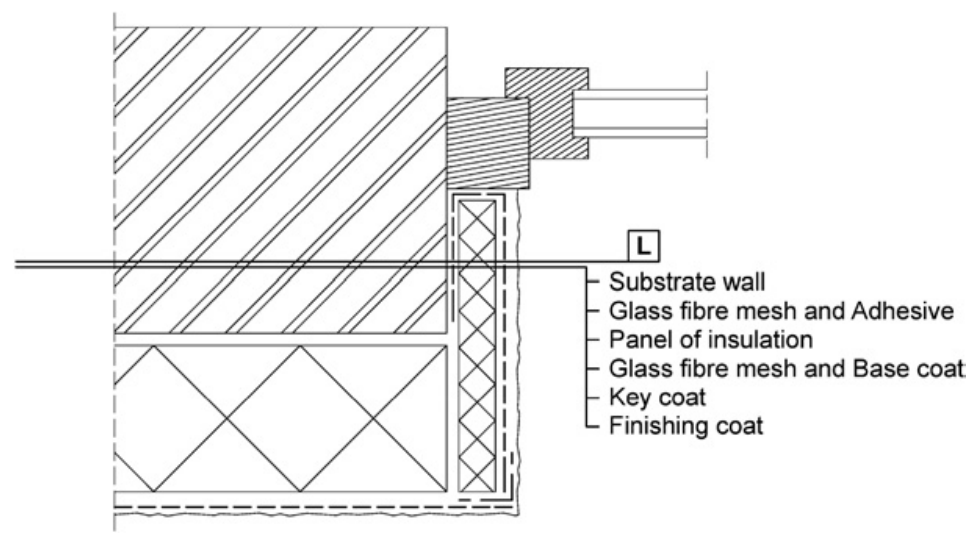

Figure 2. Embrasure detail.

the required amount. Furthermore, the expert judgements highlighted that problems were not with the components themselves but with the system as one and the details of it.

\section{IDEOLOGY}

The test standard's ideology is to test combustible insulation materials or cladding system as one 'structure'/ one system and control the details of it. The fire is modeled just like in real fire cases, flames come out from (at least) one window opening to the façade [10]. The second floor is not considered to be necessarily lost, the damage can be controlled. The test method screens whether the ETICS or cladding system contributes significantly to the fire spread or not.

Test results and real fire investigations show that the details around window openings play a significant role in the systems' fire performance. Closing the insulation core around the window opening and at the edges of the structure is the key which can be achieved by reinforcing the right amount of render by fiberglass mesh and filling the gap between the windows' frame and the panel of insulations by adhesive.

\section{CONCLUSION AS HIGHLIGHTS OF MSZ 14800-6:2009}

The test method provides

- $1: 1$ construction model with realistic details

- evaluation of the effect of fire spread in vertical and horizontal plane

- standardized temperature-time curve (connection to EN 1363-1 [11])

- sophisticated criteria and evaluation method

- results in minutes

- classification range 15 ( $\mathrm{min}), 30(\mathrm{~min})$ or 45 (min).

\section{References}

[1] MSZ 14800-6:2009 Fire resistance tests. Part 6: Fire propagation test for building facades.

[2] National Fire Code; Issued by Ministry of Internal Affairs 54/2014. (XII. 5.).

[3] MSZ EN 1634-1:2014 Fire resistance and smoke control tests for door and shutter assemblies, openable windows and elements of building hardware. Part 1: Fire resistance test for door and shutter assemblies and openable windows. 
[4] Smolka, M. et al., "Semi-natural test methods to evaluate fire safety of wall claddings", Proceedings of the $1^{\text {st }}$ International Seminar on Fire Safety of Facades, Paris, France, 14-15 November, 2013.

[5] LEPIR Test. Large scale Fire Performance testing of External wall cladding systems. LNE, 2015.

[6] SP FIRE 105. Issue 5. Large scale testing of facade systems. SP Boras Sweden, 1994.

[7] Technical Report TR073 (draft). Large Scale Fire Performance Testing of External Wall Cladding Systems. EOTA PT4 Task Group, 2013.

[8] Dr. Nataśa Knez (speaker), "Experimental large scale facade test", EGOLF Workshop on Facades Szentendre, Hungary, 29 October, 2015.

[9] Dr. Tamás Bánky, Sándor Mezei “Tényvázlat a túzkárt szenvedett miskolci panelház homlokzati hőszigetelő rendszerének viselkedéséről”, (translation: Representations of behaviour of the external insulation system of the panel building in Miskolc) Védelem (ISSN: 1218-2958), XVI. 6, 2009, p. 20-21.

[10] Dr. Tamás Bánky (speaker), "A full-scale test method for determination of fire propagation parameters on facades with openings in Hungary", Fire Safety Seminar, University of Tokyo, Tokyo, Japan, 26 August, 2015.

[11] MSZ EN 1363-1:2013 Fire resistance tests. Part 1: General requirements. 